\section{Milica Cvetković ${ }^{1}$}

Hight business school vocational studies

Prof. dr Radomir Bojković, Kruševac

Maja Cogoljević ${ }^{2}$

Hight school for business economics and entrepreneurship

Beograd

\section{Marija Ranđelović ${ }^{3}$}

City Nis
SCIENTIFIC REVIEW ARTICLE

DOI: $10.5937 /$ ekonomika2103107C

Received: May, 24. 2021.

Accepted: Jul, 11. 2021.

\title{
THE IMPACT OF ECONOMIC DEVELOPMENT ON THE EFFICIENCY OF THE FINANCIAL SECTOR
}

\begin{abstract}
A stable financial sector creates economic development. Speculative actions in financial markets cause disturbances and are an indicator of economic instability. The growth of a modern market economy more than two centuries ago is interconnected with the growth of the financial system. The averment that there is a connection between the growth of the financial and real sectors of the economy is as old as economics science. A developed financial system encourages competition, expands the market, and increases the efficiency of financial institutions. The depth and the breadth of financial markets are growing, which are transmission to the performance and structure of the economy. Through linking savings and investments, the financial system controls and manages the risks that are characteristic of financial operations and facilitates the interaction of production and consumption. The financial systems of transition countries are not sufficiently developed, so this paper aims to point out the interconnectedness and impact of the financial system on macroeconomic stability.
\end{abstract}

Key words: economic development, financial markets, economy, macroeconomic stability.

JEL classification: E00,E60,011,

\section{УТИЦАЈ ПРИВРЕДНОГ РАЗВОЈА НА ЕФИКАСНОСТ ФИНАНСИЈСКОГ СЕКТОРА}

\section{Апстракт}

Стабилни финансијски сектор обезбеђује стабилни привредни развој. Шпекулативне радње на финансијским тржситима проузрокују поремећаје

\footnotetext{
${ }^{1}$ milica.cvetkovic85@yahoo.com, ORCID ID: 0000-0002-1235-3570

${ }^{2}$ maja.cogoljevic@vspep.edu.rs, ORCID ID: 0000-0002-5766-9325

${ }^{3}$ marija.randjelovic@gu.ni.rs, ORCID ID: 0000-0001-7880-4533
} 
u показатељ су привредне нестабилности. Развој савремене тржишне економије виме од два века уназад нераскидиво је повезан са развојем финансијског система. Тврдња да постоји веза између развоја финансијског и реалног сектора привреде, стара је колико и сама економска наука. Развијен финансијски систем подстиче конкуренцију, проширује тржиште и повећава ефикасност финансијских институција. Дубина и иирина финансијских тжнита расте, што се преноси на перформансе и структуру привреде. Кроз повезивање штедюе и инвестиичја, финансијски систем контролише и управља ризицима који су карактеристични у финансијском пословағу и олакшава интеракцију производње и потрошње. Финансијски системи земалја у транзичији нису довољно развијени, стога је ичиь овог рада да укаже на повезаност и утицај финансијског система на макроекономску стабилност.

Кључне речи: привредни развој, финансијска тржишта, привреда, макроекономска стабилност.

\section{Introduction}

The economy and economic subjects perform their activities within the financial system, which are composed of a large number of participants and institutions that are in the function of companies, individuals, and governments. The main goal of every national economy is to establish a financial system that will provide economic growth. Any financial system aspires to connect savings and investments through financial markets. If the financial market is healthy, then the system is ready for quick adjustments and efforts required by any development.

Economic development implies the new needs of economic entities, which are reflected in the financial sector. Analysis of economic development and the financial sector is crucial for understanding their interdependence. In a period of slow economic development, inflation is often used as an instrument to achieve goals, and especially to stimulate employment growth. High inflation rates reduce the credit potential of banks as a financial sector, which increases liquid reserves. Interdependence exists because rising consumer prices lead to a decrease in aggregate demand, which slows down economic activity and a decline in credit demand.

Despite the existence of dilemmas about the interdependence of financial market development and economic growth, there is great agreement on the connection between economic growth and financial market development as an integral part of the financial system. "The misunderstanding arises over the question of whether the development of the financial market is the driver of development (supply argument) or economic development causes the development of the financial market (demand argument)." (Brealey Myers Marcus, 2007). Another question that arises is whether the banking or non-banking sector and the capital market are more important at a certain economic level? These and many other issues make this topic attractive for processing and analysis.

A more comprehensive understanding of the impact of the growth of the financial system on economic growth is possible if other functions of the financial system are analyzed control of business operations, risk management, and facilitation of exchange of goods and 
services. Each of these functions has an influence on the basic determinants of economic growth (accumulation of capital, technological innovation, increase in total factor productivity). In this regard, the good functioning of the financial system allows national economies to make full use of development potentials, as secure that investment projects finance at a minimal cost.

\section{Financing of economic development}

The driver of the national economy is economic development. The basis of economic growth is domestic savings, which is a deficit factor for developing countries. In such conditions, developed countries resort to engaging savings from abroad, which are the supplement the domestic savings. "Savings are a voluntary renunciation of current consumption, for the sake of higher consumption in the future." (Ristanović, 2017) Savings can be at the level of individuals, the economy, and the state. It is the savings of individuals that are the form of financing economic development in less developed national economies, while in developed countries, it is important part of the financing.

In addition to domestic savings, foreign sources of financing are of great importance to the economy. Sources financing outside the domestic one refers to foreign direct investments and portfolio investments. According to Dašić (2011), the contribution of foreign direct investment to a country and its economic development is reflected in the waning of regional inequalities. (Dašic, 2011) Economic growth is the most pertinent macroeconomic parameter, which assesses the country's progress and is appearing in terms of GDP. Economic growth is realized through GDP growth. The incentive of economic growth covers monitoring of other indicators, such as the level of capital, employment, imports, exports.

Graph 1. Structure of components that accelerate economic development

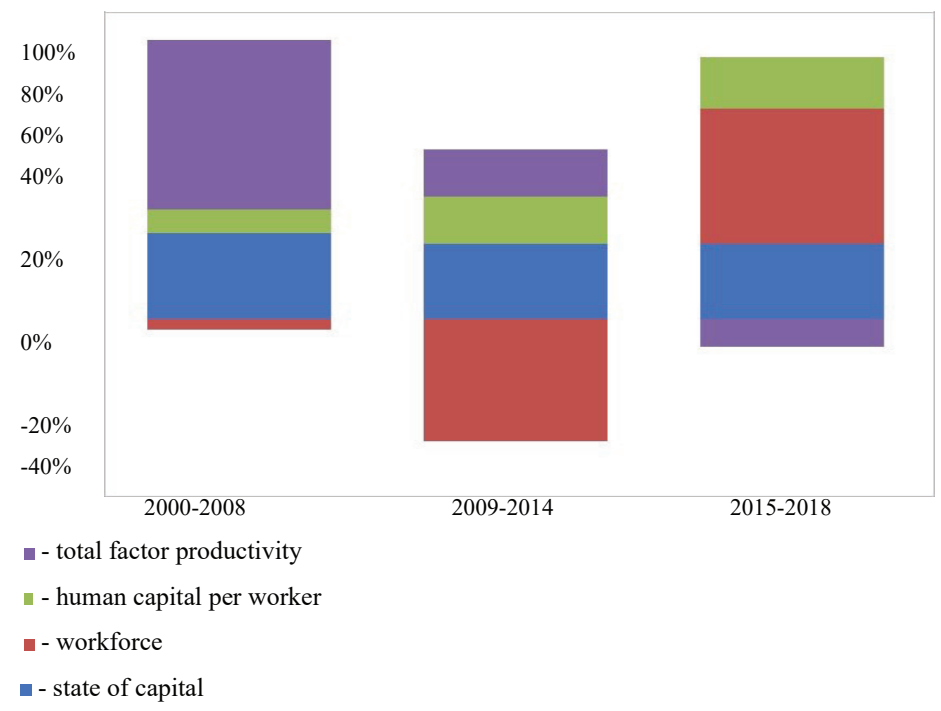

Source: World Bank budget based on SBS data total factor productivity 
Investment opportunities and institutional frameworks are often analyzed, to assess the absorption power of the economy, which further affects the different dynamics of foreign direct investment. The more developed the country, the higher the share of domestic savings in investment financing, so in developed countries, home

savings are moving from 85-95\%. (Economic Analysis Division, UN / ECCE, 2000) Conversely, less developed countries and countries in transition finance their investment activity mainly from foreign sources, foreign savings, regardless of the form in which these savings or capital come.

Direct investment is the simplest method of transferring funds from surplus to deficit entities and is probably the most efficient if the conditions are right. (Rose \& Marquis, 2012) However one of the problems of direct investment is the mismatch between the desires and economic needs of savings and investment entities. Savings mobilization is the process of pooling free funds for investment. By performing the function of mobilizing savings, the financial system overcomes the problems of connecting savings and investment entities, such as high transaction costs and a lack of information on the other side. Therefore, efficiency of the financial system in consolidating the savings of individuals can significantly affect the increase in savings, and consequently the accumulation of capital and economic growth.

The question that arises for many national economies is whether to use the domestic accumulation of foreign capital. This question has been asked by the simultaneous action and presence of inflation, the balance of payments deficit, chronic unemployment. Such relationships pose a new dilemma, which is the limit of external borrowing of the economy, what is the system of using foreign capital, but also the efficiency of its use. What is important is that foreign direct investment stimulates economic growth, but if this process is not followed by the growth of domestic savings, then it is not possible to maintain long-term and stable rates of economic growth and development.

National savings as an important source of financing economic development must imperatively respect the difference between the socio-economic environment of market economies, on the one hand, and developing countries and economies in transition, on the other. The former has an auspicious savings structure since the domestic currency is convertible there is no difference between savings in domestic and savings in foreign currencies. In economically developed countries money savings are covered by real accumulation, production of goods in whose structure, high-performance products usually dominate. Developing countries are characterized by extremely low savings in relative terms as a percentage of the social product, and especially in absolute terms. Money savings are generally not covered by real accumulation due to the destructive effect effects of inflation, while money convertibility cannot be talked about, while the financial market is underdeveloped. (Dragutinović, Cvetanović, Filipović, 2005)

If the Republic of Serbia could introduce changes that would improve each of the above components of economic development, it would lead to the expansion of the national economy. Economic growth is the result of three factors that interact with each other, capital, labor, and productivity. "Foreign direct investments, which were in the form of taking over domestic companies, made a great contribution to the economic development of the Republic of Serbia." So there was an improvement in their business, but also GDP growth. However, there was also an unsuccessful implementation of the privatization process of large companies, which made this growth not achieve even more significant results.” (Simić, 2014) 
Macroeconomic sustainability is a precondition for economic development because it reduces uncertainty for investors but also for consumers. Capital as a physical means of production should be maintained and increased through investment. Labor and human capital represent workers who use physical capital to produce economic results and whose productivity affects economic growth. Great emphasis is placed on the labor market as a key driver of economic development, especially for less developed national economies. The faster the efficiency of the labor force increases, the higher the GDP growth and the growth of wages without stimulating inflation, which ultimately has a positive coupling.

A crucial problem in financing economic growth and development for underdeveloped countries is the low volume of savings, which has stabilized for decades, and the main growth factor is the import of foreign accumulation. The factor of structural problems is related to the more dynamic growth of aggregate demand and final consumption in relation to the growth of gross domestic product.

\section{The impact of the financial sector on economic flows}

The development of a modern market economy is linked to the growth of banking and the entire financial sector. Through basic functions, risk linking, maturity transformation, banks provide depositors with investment insures, while at the same time having a high level of liquidity. On the other hand, banks are traditionally an external source of financing for both companies and household consumption. In this way, the banking sector has a large influence on economic flows.

Creating an optimal financial infrastructure will be in the function of economic growth for every national economy are an important question. It is closely related to the current socio-economic circumstances that affect the performance of the economy, strategic commitment, and future directions of development. To achieve social and development goals, it is necessary to establish a strong financial institution that will be able to significantly influence economic flows.

Weaknesses and scope of private capital in the financial system, regardless of whether it is economic motives, interests, or opportunities, can limit the basic assumptions of economic development. (Brkovic, 2013) For this reason, a large number of countries have special institutions that deal with issues of financing economic development. These institutions are an integral part of the banking and financial system and their specific purpose and goals differ from commercial banks. National development banks, which are established to support economic development, also affect the expansion of overall services provided by the banking and financial sector.

One of the definitions that best shows the essence of the existence of development banks is that they are "financial institutions established with the aim of economic development, taking into account the goals of social development and regional integration, by providing long-term financing or providing financing for projects that generate positive externalities ". (UN DESA, 2005) It is especially important to indicate long-term financing, which is the essence of the existence of development banks.

A significant statement of how banks help the growth of the real sector can be found in Bagehot (1873), who points out that a higher degree of banking development, 
through the mobilization of savings, positively stimulates the development of the economy. Bagehot's understanding of the role of banks in a market economy is the basis of the dominant view that growth in the capacity of the financial sector is beneficial to the development of the real sector of the economy. According to this paradigm, a higher level of development of financial intermediation measured by the ratio of the level of issued loans and GDP leads to a higher level of investment and a higher level of GDP. (Urošević, Živković, Božović, 2011)

In general, national financial systems, which are efficient in mobilizing savings, contribute significantly to the growth of economic activity. The financial market and financial institutions enable the efficient consolidation of existing financial assets in the economy and the financing of production technologies that require a high level of the initial investment. Besides, the pooling process allows financial intermediaries to diversify risks associated with individual investment projects and offer savers higher expected returns.

The development of the financial system implies easing credit constraints for indigent households, allowing them to undertake productive investments, such as investing in education. (Honohan P \& Beck T, 2007) In addition to long-term economic growth, financial development also has an impact on reducing inequalities in income distribution. The gap between rich and poor and the degree to which this gap changes from generation to generation are the consequence, among other things, of the availability of financial products and services and the possibility of their use by the poor.

The financial system of the Republic of Serbia, although it have passed the path of transition, has failed to develop all its elements. To what extent the financial system is ready to support economic growth, it is necessary to analyze the banking sector, financial markets, as well as the role of the state to adequately direct the most important source of financing economic growth (household savings). According to the data of the National Bank of the Republic of Serbia, the share of banks in total financial assets is about $90 \%$, while the relative share of other institutions is much smaller, which is an indicator of a one-sided and underdeveloped financial system.

Table 1. Savings of the population of the Republic of Serbia in billion dinars

\begin{tabular}{ccc}
\hline Year & Dinar savings & Foreign currency savings \\
2010 & 13,4 & 732,0 \\
2012 & 17,7 & 910,4 \\
2014 & 38,0 & 1014,3 \\
2016 & 50,3 & 1070,9 \\
2018 & 61,1 & 1075,0 \\
\hline
\end{tabular}

Source: NBS Statistics, Ministry of Finance of the Republic of Serbia

With the enactment of the Law on Public Debt Regulation in 2002 (Official Gazette of RS, No. 108/2016, 113/2017, 52/2019), the state committed itself to the return of foreign currency savings of citizens through the issuance of bonds, which is accompanied by the consolidation of the banking system and the restoration of trust. The population in the new banks led to a gradual increase in savings. The successful start of fiscal consolidation after 2014 removed the risks, but a large number of structural problems remained and are an obstacle to further growth and development. "Credit 
support of the banking sector to industrial investments and the new model of economic growth of the Republic of Serbia has remained very modest even after 2010." (Ćorovic, 2019) $\mathrm{T}$ he transition period in the Republic of Serbia is characterized by unfavorable conditions for lending to the economy (and households), so that loan users often paid interest and fees, which are the highest in Europe. Such conditions affect the outflow of capital from the real to the banking sector. (Aničić, Aničić, Kvrgić, 2019)

The importance of the financial system in the process of mobilizing savings is also indicated by historical facts. Berthélemy and Varoudakis (1996) that at the beginning of the 19th century in many countries there was enough accumulated money to finance industrialization while the main challenge was to mobilize these funds and direct them to the most productive purposes. This process required the redintegrate of a mechanism for collecting unused funds and distributing them to entrepreneurs who would invest in industrial enterprises. Continuing this area, Levin (2004) points out that the difference between developed and less developed economies is that developed financial systems have the potential to mobilize funds for large projects so that productive investments do not fail.

Globally, the financial system, performing the function of mobilizing savings, overcomes the problems of connecting savings and investment entities, such as high transaction costs and lack of information on the other side. Therefore, the efficiency of the financial system in consolidating the savings of many individuals can significantly affect the increase in savings and the accumulation of capital and economic growth. We cannot talk about economic development without emphasizing the importance of encouraging investment. Investments in all their forms must be a priority of the economic policy for the national economy to achieve a sustainable rate of economic growth.

\section{Financial sector efficiency indicators}

Banks are the most pertinent part of the financial sector of a national economy. Their growth can be follow using a large of indicators, which are defined in both theoretical and empirical literature. Empirical studies based on standard quantitative indicators for the calculation data are available in appropriate databases.

Alternative indicators of the size of the financial system include calculating the share of monetary aggregates (M1, M2, M3) in GDP. The relatively low contribution of the monetary aggregate M1 in GDP shows that the population does not keep a large part of cash outside formal financial flows, which is an indicator of a developed financial system. (Beck, Demirgüç-Kun \& Levine R, 2009) For the reliability of the obtained results, as an alternative indicator of the size of the financial sector, the share of banks' liabilities based on deposits in nominal GDP is used, which excludes cash in circulation from the wider money supply M2. To determine the effectiveness of the financial sector, the ratio of private sector claims to deposits of commercial banks is used. It shows the percentage of savings transferred to private-sector loans. Another indicator of the efficiency is the net interest margin, as the ratio of the book value of net bank interest income and total bank assets.

The condition for market liquidity is the existence of many participants, both on the supply side and on the demand side, who provide transactions at the same value as the 
previous ones. Besides, the market must it is necessary to absorb the purchase and sale of large quantities of stock exchange material, without affecting the price. The efficiency of the financial system described in this way is measured by the turnover ratio. The ratio of turnover and market capitalization shows how many times the securities have changed owners, how much the turnover is. "The ratio of total turnover to the market capitalization of companies is known as a turnover ratio or turnover rate." (Marinković, 2011) In the literature, this indicator can also be called the liquidity ratio. A small but liquid financial market has a relatively high turnover ratio, while a large but less liquid market has a relatively lower turnover ratio.

To determine the efficiency of the financial market, in addition to the liquidity ratio, the purchase range is used, which is the difference between the highest price that the buyer is willing to pay and the lowest price at which the seller is willing to sell. The small buying range is a direct consequence of the high degree of liquidity. The degree of financial market instability can be measured in several ways. One of them is volatility, which is a consequence of random changes in prices of financial instruments.

Important determinants of the growth of the financial system of the Republic of Serbia are the parameters that determine the depth of the financial system, access and use of financial services, efficiency and stability of the financial system. The parameter of financial depth shows that the financial system is a significant segment of the socioeconomic system in the Republic of Serbia. The banking sector is the most important part of the financial system Republic of Serbia, which accounts for over $90 \%$ of the total assets of the financial sector.

According to the World Bank for the Republic of Serbia, the indicator of the depth of financial institutions shows growth since 2000. The share of bank loans granted to private entities about GDP in the Republic of Serbia in 2015 was at the level of $48.2 \%$ and the share of this indicator has been growing since 2000 (when it amounted to $26.7 \%$ ), which indicates a positive impact of approved loans of economic growth ${ }^{4}$.

The relative importance of the role of the financial market concerning GDP in the Republic of Serbia shows growth. The capitalization of the stock exchange grew in the period from 2000. to 2015., while the total value of shares on the stock exchange traded reached a low share in GDP compared to the CE5 countries.

Table 2. Determinants of the development of the financial system in the Republic of Serbia, period 2005-2015. years

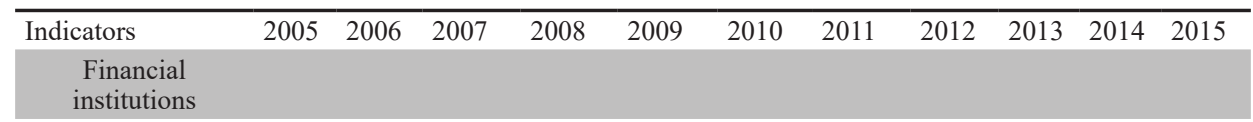

Private bank loans in relation to GDP

\begin{tabular}{|c|c|c|c|c|}
\hline 22, & 17,0 & 9,2 & 23.8 & 7,3 \\
\hline
\end{tabular}

\footnotetext{
${ }^{4}$ The average for CE5 countries in 2015 was $64.4 \%$, while the share of approved loans in GDP in the euro area was $119.8 \%$.
} 


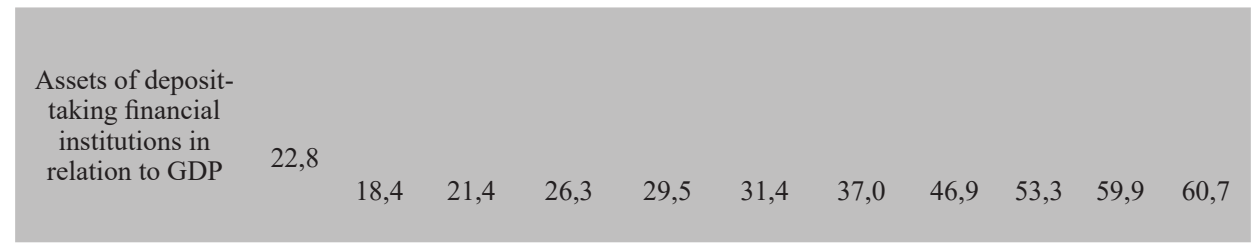

Financial markets

$\begin{gathered}\text { Total value of } \\ \text { shares traded in } \\ \text { relation to GDP }\end{gathered}$

\section{Source: World Bank}

According to the indicators that determine the efficiency of the financial system, it is concluded that in the Republic of Serbia the efficiency of financial institutions is at a higher level concerning the efficiency of the financial market. The efficiency of the financial system is burdening by the growth of operating costs, which show a growth trend much higher concerning countries with the same level of development. The stability of the financial system of the Republic of Serbia has maintained thanks to the liquidity of the banking sector, which after the global crisis in 2009 showed a downward trend and since 2010 a gradual upward trend.

The model of economic growth after 2008, which is based on the growth of exports and investments, is largely conditioned by economic trends, but also by the strengthening of external demand. It is very important to stimulate state and private investments and fulfill the preconditions for better business, such as a more efficient financial system, efficient administration, and improved competitiveness. In the area of financial sector growth, it is necessary to establish financial discipline and efficiently resolve problem loans, the banking sector is a dominant part of the financial system.

\section{Conclusion}

Economic growth and development of the national economy depend on numerous factors, in addition to the development of the financial system, time is also important factor. The economic development of countries in transition lags behind that of developed countries, where one of the main reasons is the insufficient fragmentation of financial markets. The main reason for the underdevelopment of the financial market 
is underdeveloped institutions and the fact that access to external sources of financing is limited. Economic growth indicates the depth and capacity of the financial system, including the availability and liquidity of credits, share capital, insurance, and other financial products.

The interdependence and interaction between economic growth and financial stability are manifested through financial markets, which enable risk-taking and financing of more productive and risky projects. Developed financial markets facilitate the process of risk diversification while providing SMEs with access to finance. Through capital allocation, the financial system provides a higher level of project productivity. A developed financial system provides an efficient payment system, which significantly reduces transaction costs. If the structure of the financial system is disrupted, there is not only a disturbance in financial intermediation but also an outflow of capital. That is why a stable, resilient, and regulated financial system is the basis for a stable economy.

Financial support to the economy and expensive business loans are the leading factors in the unfavorable economic environment. The unavailability of additional financial resources is a limiting factor for the growth and development of the economy. The stability of the financial system and the development of the financial market depend primarily on general reforms, which create more favorable business environment and improving basic macroeconomic indicators can contribute to the progress of this segment. The financial markets are not perfect, priority of modern economic systems is to mobilize savings at the lowest possible cost. More efficiently mobilize savings, it is desirable to perform internal diversification of the financial sector, through the activation of diversified forms of banking.

The creators of economic policy are set a great task, to create such an environment that will have a positive effect on the financial system with the help of adequate economic measures. In the Republic of Serbia is concerned, it is necessary to continuously monitor the dynamics of bank loans and accompanying risks, special attention must be paid to the low share of loans to the private sector in GDP and at the same time high share of nonperforming loans in the total loan portfolio. For all the above activities to give positive outcomes, first of all, political stability and the existence of a democratic society are necessary as necessary preconditions for the development of the financial and economic system of a country.

\section{Reference}

Aničić, J. Aničić, D. Kvrgić, G. (2019) Sustainable growth and regional competitivenss of Serbian economy, pp.65, Ekonomika, Niš.

Beck T Demirgüç-Kun A \& Levine R (2009) Financial Institutions and Markets across Countries and over Time. Policy Research Working Paper No 4943. The World Bank.

Breley Myers Marcus (2007) Osnove korporativnih finansija, peto izdanje, MATE, Zagreb.

Brković, M. (2013) Restrukturiranje bankarskog sektora i doprinos privrednom razvoju u tranzicionim uslovima, Ekonomski fakultet Niš, str. 173 
Ćorović, E, (2019) Strukturni problemi finansiranja privrednog rasta Republike Srbije, Državni univerzitet u Novom Pazaru, Departman za ekonomske nauke.

Dašić, B. (2011) Strane direktne investicije kao pokazatelj regionalnih neravnomernosti u Srbiji i mogućnosti njihove efikasne alokacije, Ekonomski horizonti, br. 1/13, Ekonomski fakultet, Kragujevac.

Dragutinović, D. Cvetanović, S. Filipović, M. (2005) Teorija privrednog rasta i razvoja, Ekonomski fakultet, Beograd.

Honohan P \& Beck T (2007) Making Finance Work for Africa. The World Bank.

Financing growth and development in the transition countries, The role of domestic savings, Economic Analysis Division, UN/ECCE, 2000.

Marinković, S. (2011) Finansijska tržišta, Ekonomski fakultet, Niš, str.7

Ristanović, V. (2017) Monetarna ekonomija, Visoka škola za poslovnu ekonomiju i preduzetništvo, Beograd, str.22.

Rose, P. S. \& Marquis, M. H. (2012) Finansijske institucije i tržišta, Udruženje banaka Srbije, Beograd.

Simić. V, (2014) Privredni i ekonomski razvoj Srbije - dugoročan i spor proces, Ekonomika, Niš.

Službeni glasnik RS, br.108/2016, 113/2017, 52/2019

Urošević, B. Živković, B. Božović, M. (2011) Uticaj finansijskog sektora na realni sektor privrede, Ekonomika, Niš, str. 35.

UN DESA (2005) Rethinking the role of development banks, ad hoc expert group meeting, December 1-2, New York. 
